D0I:10.17951/we.2020.6.2.201-205 $\quad$ Wschód Europy • Восток Европы • East of Europe vol 6, 2 / 2020

Anna Skibińska

Uniwersytet Wrocławski

ORCID ID: https://orcid.org/0000-0002-6097-2122

\title{
Recenzja książki: Informacyjny wymiar wojny hybrydowej, red. Marek Wrzosek, Szymon Markiewicz, Zbigniew Modrzejewski, Akademia Sztuki Wojennej, Warszawa 2018, ss. 183
}

$\square$ ojęcie wojny hybrydowej w literaturze naukowej stało się szczególnie popularne za sprawą konfliktu, jaki wybuchł w 2014 roku na wschodzie Ukrainy. Choć początkowo ten bezprecedensowy konflikt określano w niejednolity sposób, używając takich określeń, jak np.: „wojna nieliniowa”, „wojna specjalna” ${ }^{1}$, „wojna kontrolowanego chaosu" ${ }^{2}$, to jednak ostatecznie utrwaliło się w piśmiennictwie pojęcie „wojna hybrydowa" jako najlepiej oddające charakter działań na Donbasie ${ }^{3}$.

Pomimo że w ostatnich kilku latach wielu autorów podejmowało ten temat ${ }^{4}$, przed wydaniem recenzowanej monografii na rynku wydawniczym nie było pozycji, która w sposób wyczerpujący omawiałaby informacyjne aspekty konfliktów hybrydowych. Dlatego należy podkreślić, że książka pod redakcją naukową Marka Wrzoska, Szymona Markiewicza i Zbigniewa Modrzejewskiego wypełnia dostrzeżoną lukę badawczą, a jednocześnie może inspirować następnych badaczy do przyjrzenia się innym ele-

1 Tak m.in. w wypowiedziach przedstawicieli Organizacji Traktatu Północnoatlantyckiego (NATO) - por. s. 41 recenzowanej monografii.

2 Por. O. Wasiuta, S. Wasiuta, Wojna hybrydowa Rosji przeciwko Ukrainie, Wydawnictwo Arcana, Kraków 2017, s. 33-34.

3 Należy jednak podkreślić, że wciąż nie ma zgody co do uniwersalnej definicji tego pojęcia, o czym szerzej w dalszej części recenzji.

4 Zob. m.in. O. Wasiuta, S. Wasiuta, Wojna hybrydowa Rosji przeciwko Ukrainie, Wydawnictwo Arcana, Kraków 2017; A. Antczak-Barzan, Z. Śliwa, R. Zaniewski, Wojna XXI wieku. Początki wojny „trzeciej fali”, Wydawnictwo Vizja Press \& IT, Warszawa 2016; Wspótczesne aspekty bezpieczeństwa państwa, red. A. Piędel, J. Pomiankiewicz, A. Żebrowski, Wyższa Szkoła Bezpieczeństwa i Ochrony im. Marszałka J. Piłsudskiego w Warszawie, Nisko 2016, a z zagranicznych pozycji: A. Wilson, Ukraine Crisis: What it Means for the West, Yale University Press, New Heaven 2014; R. Szwed, Framing of the Ukraine-Russiaconflict in online and social media, All rights reserved by the NATO StratCom Riga, May 2016. 
mentom tak ważnej, aktualnej, a przy tym wielowymiarowej problematyki. Redaktorzy naukowi reprezentują Akademię Sztuki Wojennej: Zakład Rozpoznania Wojskowego i Walki Radioelektronicznej - jego kierownikiem jest ppłk dr Szymon Markiewicz, zaś do kadry naukowo-dydaktycznej należy prof. dr hab. inż. Marek Wrzosek, oraz Zakład Działań Informacyjnych, którego kierownikiem jest ppłk dr Zbigniew Modrzejewski.

Monografia składa się ze wstępu, czterech rozdziałów i zakończenia, zaś na końcu znajdziemy jeszcze wykaz literatury oraz spis rysunków, fotografii i tabel. Książka powstała jako efekt grantu badawczego, którego temat brzmiał: „Uwarunkowania funkcjonowania systemu rozpoznania wojskowego w warunkach wojny hybrydowej". Autorzy w kompleksowy sposób omówili zagadnienie wojny hybrydowej na przykładzie konfliktu rosyjsko-ukraińskiego, przedstawiając najważniejsze aspekty prowadzonych działań informacyjnych.

$\mathrm{W}$ ramach wprowadzenia $\mathrm{w}$ pierwszym rozdziale zaprezentowano obszerne zestawienie bibliograficzne odnoszące się do pojęcia „konflikt hybrydowy”. Wnikliwa analiza objęła zarówno teksty zagranicznych autorów, jak i publikacje krajowe - oddzielny fragment poświęcono wydawnictwom zwartym, osobno scharakteryzowano zaś komentarze i artykuły z wydawnictw periodycznych („Zeszytów Naukowych Akademii Obrony Narodowej”, miesięcznika „Raport. Wojsko. Technika. Obronność” oraz „Kwartalnika Bellona”). Co ważne, przeglądu literatury dokonano w bardzo uporządkowany sposób, nawiązując do trzech kontekstów: historyczno-terytorialnego, teoretycznego i metodologicznego, a oprócz analizy treści publikacji zwrócono także uwage na reakcje, jakie dany tekst wywołał, oraz dodano własne uwagi krytyczne. Zdając sobie sprawę z korzyści, jakie wynikają z interdyscyplinarnego podejścia do tego tematu, nie ograniczono się tylko do literatury z zakresu nauk o obronności i bezpieczeństwie, lecz sięgnięto również po publikacje z zakresu nauk o polityce i politologii.

Streszczenie najważniejszych tez głoszonych przez poszczególnych autorów pozwala czytelnikowi zdobyć wpierw podstawową orientację w temacie, który jest przedmiotem niniejszej monografii. Dzięki temu nabywamy stopniowo coraz większe kompetencje do samodzielnego zgłębiania źródeł oraz dostrzegania nowych obszarów działań w hybrydowych konfliktach (m.in. dotyczących cyberprzestrzeni, operacji psychologicznych i informacyjnych). Ciekawe jest zwłaszcza przedstawienie doktryny wojennej Federacji Rosyjskiej z 2014 roku oraz rosyjskiej koncepcji wojny hybrydowej, która interpretowana jest $\mathrm{z}$ jednej strony pod kątem fenomenologicznym, zaś z drugiej „jako technologia służąca do wywierania politycznego wpływu” (s. 48). Winą za jej stosowanie strona rosyjska obarcza Stany Zjednoczone Ameryki, których celem miałaby być światowa hegemonia. Perspektywę tę poszerzają przykłady innych (obok rosyjsko-ukraińskiej) wojen, jakie w piśmiennictwie uznano za konflikty hybrydowe - m.in. rosyjsko-czeczeńskiej oraz izraelsko-libańskiej. Ponadto cenne jest nakreślenie sposobów nominacji kryzysu rosyjsko-ukraińskiego. Wszak aż do 3 lipca 2014 roku w oficjalnych wypowiedziach przedstawicieli Organizacji Traktatu Północnoatlantyckiego ${ }^{5}$ nie wy-

Dalej jako NATO. 
stępowało określenie „wojna hybrydowa”. Zamiast tego mówiono m.in. o „wojnie nieliniowej" (ang. non-linear war) lub „wojnie specjalnej” (ang. special war), co dodatkowo wzmacnia tezę o braku zgody co do jego semantyki (s. 41). Wspomniane przy tej okazji pojęcie tzw. „wojen limitroficznych" (używane m.in. przez Wadima Cymburskiego oraz Natalię Komlewą) skłania do refleksji na temat językowego obrazu świata oraz jego granic i przystawalności tych obrazów w różnych częściach globu'.

Dodatkowy walor poczynionych analiz znajdujemy w podsumowaniu pierwszego rozdziału, w którym autorzy formułują najważniejsze wnioski, wynikające ze skrupulatnego przeglądu obszernej literatury. Zwracają oni uwagę na dominację opracowań odnoszących się do zagrożeń w regularnych operacjach militarnych i stosunkowo niewielką liczbę publikacji, które bezpośrednio charakteryzowałyby konflikt hybrydowy. Podkreślane są przy tym trudności w opisywaniu konfliktu na wschodzie Ukrainy, który wciąż trwa, a dostęp do rzetelnej wiedzy na jego temat bywa utrudniony. Ostatecznie autorzy stwierdzili, że nie jest współcześnie możliwe jednoznaczne zdefiniowanie terminu „konflikt hybrydowy”. W dostępnych publikacjach wymieniane są różne cechy dystynktywne - część z nich jest wspólna (powszechnie akceptowana), ale niektóre pojawiają się tylko u wybranych autorów, m.in. „konflikt nowego wieku” czy „nowa jakość prowadzenia wojny" - pojęcie to wciąż czeka na pełniejsze dookreślenie.

W rozdziale drugim, zatytułowanym Deskrypcja wojny hybrydowej, dowiadujemy się o kolejnych definicyjnych trudnościach - tym razem dotyczących określania poszczególnych działań (tak militarnych, jak i niemilitarnych), jakie towarzyszą zwykle wojnie hybrydowej. Rozważania inicjują ogólne uwagi na temat przeplatających się okresów wojny i pokoju na świecie oraz sposobu rozumienia słów „wojna” i „hybryda”. Następnie autorzy dochodzą do wniosku, iż wojna hybrydowa łączy cztery odmiany zagrożenia: tradycyjne (regularne), nieregularne, terroryzm i technologię informacyjną. Zwłaszcza ostatnie z nich jest w tej części książki szczegółowo omówione. Wskazano tu m.in. na podział operacji informacyjnych na pasywne lub aktywne i coraz istotniejsze miejsce działań psychologicznych. Pierwszorzędną rolę w ich upowszechnianiu spełniają obecnie media, których analizę (na przykładzie konfliktu rosyjsko-ukraińskiego) przedstawiono - podkreślając dwa uzupełniające się w środkach masowego przekazu elementy, tj. dezinformację oraz propagandę. Warto zaznaczyć, że funkcje działań psychologicznych są tu ukazane w szerokim kontekście i na wielu przykładach, które zwracają uwagę na zaangażowanych po stronie „czwartej władzy” polityków i służb specjalnych. Ponadto autorzy zdają sobie sprawę, że niektóre efekty psychologicznych działań (długofalowych) możemy niekiedy obserwować z opóźnieniem, stąd pełne opisanie wyników „walki o serca i umysły” w Rosji i Ukrainie nie jest dziś jeszcze możliwe (s. 70). Podsumowaniem tego rozdziału jest studium przypadku konfliktu rosyjsko-ukraińskiego. Prowadzi ono do skonstruowania scenariusza przebiegu wojny hybrydowej, w którym, obok działań militarnych, przeanalizowano działania dyploma-

6 Por. słynne zdanie Ludwiga Wittgensteina zawarte w Tractatus logico-philosophicus: „Granice naszego języka są granicami naszego świata”. 
tyczne, walkę informacyjną, presję ekonomiczną i polityczną oraz zarysowano prognostyczne scenariusze „rozwoju wypadków” (s. 76-84).

Rozdział trzeci (Dominacja informacyjna w wojnie hybrydowej) odnosi się już stricte do działań na informacjach, jakie wiążą się dziś z konfliktem hybrydowym i wykorzystywane są w coraz większym zakresie. Interesujące jest przedstawienie przez autorów rosyjskich dokumentów doktrynalnych, które mówią o strategicznym wykorzystywaniu informacji. Prześledzenie ich ewolucji pozwala stwierdzić, że o ile w 2000 roku bezpieczeństwo informacyjne uznawano w Federacji Rosyjskiej przede wszystkim za element obronny, o tyle 16 lat później (5 grudnia 2016 prezydent Władimir Putin zatwierdził nową doktrynę) mowa jest wprost o konieczności „zbudowania silnych zdolności ofensywnych dla prowadzenia cyberoperacji” (s. 94). W tej części książki znajdziemy też porównanie netwojny (wojny sieciowej) z wojną informacyjną, rozważania na temat uzbrojonej informacji, technik wywierania wpływu oraz zarządzania refleksyjnego w kontekście wojny informacyjnej i konfliktów hybrydowych. Obrazowe przykłady fake newsów raz jeszcze dobitnie potwierdzają niekwestionowaną rolę mediów w walce o ludzką świadomość.

Ostatni rozdział (Radioelektroniczny wymiar wojny hybrydowej) zawiera opis metod walki radioelektronicznej podczas konfliktu hybrydowego i ma częściowo charakter prognostyczny. Autorzy opisują środowisko operacyjne walki radioelektronicznej i rolę tej walki w działaniach hybrydowych. Szczególnie cenne, z praktycznego punktu widzenia, jest wskazanie na możliwość wykorzystania radioelektronicznych narzędzi zarówno do działań ofensywnych, jak i obronnych. Ważne są również rekomendacje zawarte w podsumowaniu, które mogą zainspirować władze państwowe do priorytetowego traktowania zabezpieczeń informacji przesyłanych w sieciach bezprzewodowych oraz ochrony informacji źródłowych przed ich przejęciem bądź utratą.

Reasumując, omawiana monografia stanowi bardzo wartościowe źródło wiedzy na temat wojny hybrydowej, a zwłaszcza jej informacyjnego wymiaru. Dzięki przytoczeniu wielu przykładów z najnowszej historii, czytelnik, oprócz uporządkowanej teorii, otrzymuje też możliwość lepszego poznania współczesnej geopolityki. Specjalistyczny język i precyzyjna terminologia z dyscypliny nauk o obronności stanowią wartość dla znawców tego obszaru, a jednocześnie - za sprawą m.in. wielu wyliczeń, podsumowań i poglądowych egzemplifikacji - książka jest także zrozumiała dla badaczy z pokrewnych dziedzin. Pozostaje wierzyć, iż publikacja ta zainteresuje również osoby odpowiedzialne za politykę informacyjną państwa i pozwoli w efekcie stworzyć infrastrukturę niezbędną do przeciwdziałania potencjalnym konfliktom hybrydowym.

\section{Bibliografia}

Antczak-Barzan A., Śliwa Z., Zaniewski R., Wojna XXI wieku. Początki wojny "trzeciej fali”, Wydawnictwo Vizja Press \& IT, Warszawa 2016.

Współczesne aspekty bezpieczeństwa państwa, red. A. Piędel, J. Pomiankiewicz, A. Żebrowski, Wyższa Szkoła Bezpieczeństwa i Ochrony im. Marszałka J. Piłsudskiego w Warszawie, Nisko 2016. 
Pobrane z czasopisma Wschód Europy http://journals.umes.pl/we

Data: 26/04/2023 16:32:25

Szwed R., Framing of the Ukraine-Russiaconflict in online and social media, All rights reserved by the NATO StratCom Riga, May 2016.

Wasiuta 0., Wasiuta S., Wojna hybrydowa Rosji przeciwko Ukrainie, Wydawnictwo Arcana, Kraków 2017. Wilson A., Ukraine Crisis: What it Means for the West, Yale University Press, New Heaven 2014.

Wittgenstein L., Tractatus logico-philosophicus, Wydawnictwo Naukowe PWN, Warszawa 2020. 